Original Research Paper

\title{
EFEKTIFITAS TERAPI RELAKSASI AUTOGENIK DAN AROMA TERAPI LAVENDER TERHADAP PENURUNAN TINGKAT KECEMASAN PASIEN DI RUANG ICU RSUD POSO
}

\section{Agusrianto, Nirva Rantesigi, Dewi Nurviana Suharto*}

\section{Poltekkes Kemenkes Palu}

\section{Email Corresponding: \\ dewinurviana.suharto@gmail.com}

Page : $141-146$

\section{Kata Kunci :}

Aromaterapi lavende;

kecemasan;

relaksasi autogenic.

\section{Keywords:}

lavender aromatherapy, anxiety,

Autogenic relaxation

\begin{abstract}
ABSTRAK
Pasien yang di rawat di ICU tentunya akan mengalami masalah psikis, berupa gangguan cemas, depresi hingga psikosis. Cemas yang tidak ditangani akan menyebabkan keadaan pasien semakin buruk seperti mengalami irama jantung yang tidak beraturan, nadi cepat, sesak nafas dan sakit kepala. Penatalaksanaan untuk mengatasi kecemasan dapat dilakukan dengan relaksasi autogenic dan aromaterapi lavender. Tujuan penelitian ini untuk mengetahui efektifitas terapi relaksasi autogenic dan aromaterapi lavender terhadap penurunan tingkat kecemasan pasien di ruang ICU RSUD Poso. Metode penelitian Quasiexperimental dengan rancangan penelitian pre-test and post-test with control group. Populasi adalah semua pasien yang smenjalani rawat inap di ruang ICU pada bulan Agustus s/d Oktober 2020. Jumlah sampel sebanyak 30 orang dengan Tehnik pengambilan sampel menggunakan purposive sampling sesuai dengan kriteria inklusi. pengumpulan data menggunakan Instrument kuesioner HARS. Hasil penelitian menunjukkan bahwa ada perbedaan kecemasan sebelum dan setelah diberikan intervensi relaksasi autogenic dan aromaterapi lavender pada kelompok intervensi dengan $\mathrm{p}$ value $=0,000$. Intervensi relaksasi autogenic dan aromaterapi lavender dapat dijadikan intervensi mandiri dalam mengatasi masalah kecemasan.
\end{abstract}

\section{ABSTRACT}

Patients who are treated in the ICU will certainly experience psychological problems, in the form of anxiety disorders, depression to psychosis. Untreated anxiety will cause the patient's condition to get worse, such as experiencing irregular heart rhythms, rapid pulse, shortness of breath, and headaches. Management to overcome anxiety can be done with autogenic relaxation and lavender aromatherapy. The purpose was to determine the effectiveness of autogenic relaxation therapy and lavender aromatherapy in reducing the anxiety level of patients in the ICU Poso Hospital. Quasi-experimental research method with pre-test and post-test research design with the control group. The population was all patients who were hospitalized in the ICU from August to October 2020. The total sample was 30 people with the purposive sampling technique using purposive sampling by the inclusion criteria. Data collection using the HARS questionnaire instrument. The results showed that there were differences in anxiety before and after being given autogenic relaxation intervention and lavender aromatherapy in the intervention group with a p-value $=0.000$. Autogenic relaxation interventions and lavender aromatherapy can be used as independent interventions in overcoming anxiety problems.

\section{PENDAHULUAN}

Kecemasan adalah perasaan tidak santai karena rasa takut yang disertai suatu respon (penyebab tidak spesifik atau tidak diketahui oleh individu) ${ }^{1}$. Kecemasan dalam psikologi didefinisikan sebagai perasaan takut mengenai masa mendatang tanpa sebab khusus serta bersifat individual $^{2}$.

$$
\text { Organisasi Kesehatan Dunia (WHO, }
$$
2017) menyatakan bahwa depresi dan kecemasan merupakan gangguan jiwa umum yang prevalensinya paling tinggi. Lebih dari 
200 juta orang di seluruh dunia $(3,6 \%$ dari populasi) menderita kecemasan ${ }^{3}$ Menurut catatan Riset Kesehatan Dasar (Riskesdas) dari Kementrian Kesehatan Republik Indonesia (2018), prevalensi gangguan emosional pada penduduk berusia 15 tahun ke atas, meningkat dari $6 \%$ di tahun 2013 menjadi $9,8 \%$ di tahun 2018. Prevalensi penderita kecemasan di tahun 2018 sebesar $6,1 \%{ }^{4}$

Pasien kritis merupakan pasien dengan kondisi yang mengancam jiwa. Pasien kritis dirawat di ruang ICU (Intensive Care Unit) memiliki nilai kematian dan nilai kesakitan yang tinggi. Pasien kritis sangat erat kaitannya dengan perawatan secara intensif serta monitoring penilaian terhadap setiap tindakan yang dilakukan kepada pasien dan membutuhkan pencatatan medis secara kontinyu dan berkesinambungan ${ }^{5}$. Pasien yang di rawat di ICU tentunya akan mengalami masalah psikis, masalah psikis dapat terjadi berupa gangguan cemas, depresi hingga psikosis ${ }^{5}$. Cemas dapat melemahkan kondisi pasien jika tidak ditangani akan menyebabkan keadaan pasien semakin buruk seperti mengalami irama jantung yang tidak beraturan, nadi cepat, sesak nafas dan sakit kepala ${ }^{6}$.

Penatalaksanaan untuk mengatasi kecemasan dapat dilakukan dengan dua cara, yaitu manajemen farmakologi dan manajemen non farmakologi. Manajemen farmakologi yaitu pemberian obat yang mampu menghilangkan rasa cemas. Sedangkan manajemen non farmakologi merupakan manajemen untuk menghilangkan kecemasan menggunakan aromaterapi, teknik relaksasi, terapi hypnothis, imajinasi terbimbing/guide imagery, terapi music dan massage ${ }^{7}$.

Relaksasi autogenik adalah relaksasi bersumber dari diri sendiri dengan kalimat pendek yang bisa membuat pikiran menjadi tenang ${ }^{8}$. Aromaterapi yang digunakan pada individu yang mengalami kecemasan yaitu aromaterapi lavender. Minyak lavender mempunyai banyak potensi karena memiliki beberapa kandungan seperti, limonene, geraniol lavandulol, nerol dan sebagian besar mengandung linalool dan linalool asetat dengan jumlah sekitar 30-60\%, dimana linalool adalah kandungan aktif utama sebagai relaksasi untuk mengurangi kecemasan. Dari beberapa penelitian sebelumnya terapi relaksasi autogenik dan aromaterapi lavender sama-sama baik dalam menurunkan kecemasan, Penelitian ini bertujuan untuk mengidentifikasi kombinasi kedua intervensi tersebut dalam menurunkan kecemasan pada pasien ICU di RSUD Poso.

\section{BAHAN DAN CARA}

Metode yang digunakan dalam penelitian ini adalah kuantitatif pendekatan Quasi-experimental dengan rancangan penelitian pre-test and post-test with control group. Pengambilan sampel secara non probability sampling yaitu menggunakan purposive sampling terhadap 30 orang di ruang ICU. Pengukuran kecemasan menggunakan kuesioner HARS kemudian hasil penelitian dianalisis menggunakan uji paired T test

\section{HASIL}

\section{Analisis Univariat}

Karakteristik responden dalam penelitian ini terdiri atas umur, jenis kelamin dan pekerjaan pasien. Berdasarkan hasil penelitian di deskripsikan karakteristik responden sebagai berikut :

Tabel 1 : Karateristik responden berdasarkan Umur, Jenis Kelamin dan Pekerjaan

\begin{tabular}{lcc}
\hline $\begin{array}{c}\text { Karakteristik } \\
\text { Responden }\end{array}$ & Frekuensi & $\begin{array}{c}\text { Presentase } \\
(\%)\end{array}$ \\
\hline Umur & & \\
\hline 5-11 Tahun & 2 & 6,7 \\
\hline 12-25 Tahun & 7 & 23,3 \\
\hline 26-40 Tahun & 14 & 46,7 \\
\hline 46-70 Tahun & 7 & 23,3 \\
\hline
\end{tabular}




\begin{tabular}{lcc}
\hline Jenis Kelamin & & \\
\hline Laki-laki & 12 & 40 \\
\hline Perempuan & 18 & 60 \\
\hline Pekerjaan & & \\
\hline Petani & 3 & 10 \\
\hline PNS & 4 & 13,3 \\
\hline Wiraswasta & 20 & 66,7 \\
\hline Pelajar & 2 & 6,7 \\
\hline IRT & 1 & 3,3 \\
\hline Total & $\mathbf{3 0}$ & $\mathbf{1 0 0 , 0}$ \\
\hline
\end{tabular}

Berdasarkan tabel 1 didapatkan mayoritas umur subjek penelitian adalah 26-40 tahun yang berjumlah 14 orang (46,7\%), mayoritas jenis kelamin subjek penelitian adalah perempuan yang berjumlah 18 orang $(60 \%)$ dan mayoritas pekerjaan subjek penelitian adalah wiraswasta yang berjumlah 20 orang $(66,7 \%)$.

\section{Analisa Bivariat}

Tabel 2 : Skor Rerata Kecemasan Subjek Penelitian Sebelum \& Sesudah diberikan Terapi Autogenik dan Aromaterapi Lavender Pada Kelompok Kontrol \& Kelompok Intervensi

\begin{tabular}{|c|c|c|c|c|c|}
\hline \multirow{2}{*}{ Variabel } & \multirow{2}{*}{ Mean } & \multirow{2}{*}{ SD } & \multicolumn{2}{|c|}{$95 \%$} & \multirow{2}{*}{$\begin{array}{c}\text { P- } \\
\text { Value }\end{array}$} \\
\hline & & & Upper & Lower & \\
\hline \multicolumn{6}{|c|}{ Kelompok Intervensi } \\
\hline $\begin{array}{l}\text { Kecemasan } \\
\text { sebelum } \\
\text { Intervensi }\end{array}$ & 26,2 & 4,91 & \multirow{2}{*}{5,55} & \multirow{2}{*}{3,64} & \multirow[b]{2}{*}{0,000} \\
\hline $\begin{array}{l}\text { Kecemasan } \\
\text { setelah } \\
\text { intervensi }\end{array}$ & 21,6 & 3,94 & & & \\
\hline \multicolumn{6}{|c|}{ Kelompok Kontrol (Perawatan Standar) } \\
\hline $\begin{array}{l}\text { Kecemasan } \\
\text { sebelum } \\
\text { Intervensi }\end{array}$ & 28,5 & 5,26 & \multirow{2}{*}{1,00} & \multirow{2}{*}{0,19} & \multirow{2}{*}{0,007} \\
\hline $\begin{array}{l}\text { Kecemasan } \\
\text { setelah } \\
\text { intervensi }\end{array}$ & 27,9 & 4,90 & & & \\
\hline
\end{tabular}

Berdasarkan table 2 menunjukkan perbedaan kecemasan responden sebelum dan setelah intervensi pada kelompok intervensi dan kelompok control. Kecemasan sebelum dan setelah pada kelompok kontrol menggunakan uji paired $\mathrm{T}$ test diperoleh pvalue $=0,007$ $(\mathrm{p}<0,05)$ sedangkan pada kelompok intervensi diperoleh pvalue $=0,000(\mathrm{p}<0,005)$ maka,

dapat disimpulkan ada perbedaan skor kecemasan sebelum dan setelah pemberian intervensi terapi relaksasi autogenic dan aromaterapi lavender pada kelompok intervensi dan kelompok control.

\section{PEMBAHASAN}

\section{Karakteristik Responden}

1. Umur

Hasil penelitian dilihat pada table 1 menunjukkan bahwa mayoritas umur subjek penelitian adalah 26-40 tahun yang berjumlah 14 orang $(46,7 \%)$.

Kemampuan individu dalam menggunakan koping yang positif dipengaruhi oleh kedewasaan yang dilihat dari usia seseorang. Mekanisme koping yang positif dan pengalaman hidup yang dimiliki oleh seseorang sesuai dengan kematangan usianya akan mengurangi yang dikoping mekanisme seseorang sehingga individu yang lebih dewasa sukar untuk mengalami kecemasan karena setiap individu mempunyai kemampuan adaptasi yang lebih besar terhadap kecemasan dibandingkan usia yang belum dewasa ${ }^{9}$. Terbukti pada penelitian didapatkan usia yang matur yaitu usia 4670 tahun prevalensi tingkat kecemasannya lebih sedikit dibandingkan dengan usia pertengahan, dari hasil penelitian usia 2640 tahun mayoritas mengalami kecemasan. Hasil penelitian ini sesuai dengan penelitian Budiman. F et al, (2015) yaitu terdapat hubungan antara usia dengan tingkat kecemasan. Angka prevalensi kecemasan pada pasien preoperasi dalam kategori tinggi yaitu sebanyak $83 \%$ responden dari usia remaja dan lansia mengalami kecemasan dari yang ringan sampai berat. Diny Vellyana (2017) menyatakan terdapat hubungan antara usia dengan kecemasan dengan Pvalue menunjukkan $0,036<0,5$ yang berarti bahwa terdapat hubungan yang 
signifikan antara usia dengan tingkat kecemasan

2. Jenis kelamin

Hasil penelitian dilihat pada table 1 menunjukkan bahwa mayoritas jenis kelamin subjek penelitian adalah perempuan yang berjumlah 18 orang (60\%). Selain usia jenis kelamin juga mempengaruhi kecemasan Berdasarkan hasil penelitian perempuan cenderung mengalami kecemasan dari pada laki-laki, hal ini dikarenakan pada penelitian ini perempuan berada pada usia menopause. Pada saat menopause hormone etrogen dan progesterone menurun dan menyebabkan gejala psikologis yang ditandai dengan sikap mudah tersinggung, depresi, cemas, menurunnya daya ingat (Manuaba, 2009).

Progesterone akan mempengaruhi hormone lain dari segi fisik dan psikis dapat mengaktivasi amigdala yang merupakan bagian dari system limbic yang berhubungan dengan komponen emosional dari otak. Respon neurologic dari amigdala yang merupakan bagian dari system limbic. Respon neurologis dari amigdala ditransmisikan dan menstimulasi respon hormonal dari hipotalamus. Hipotalamus akan melepaskan hormone CRF (corticotropin-releasing factor) yang menstimulasi hipofisis untuk melepaskan hormon lain yaitu ACTH (adrenocorticotropic hormone) ke dalam darah. ACTH sebagai gantinya menstimulasi kelenjar adrenal untuk menghasilkan kortisol ${ }^{10}$. Hasil penelitian ini sejalan dengan penelititian Diny Vellyana (2017) hasil p-value 0,043 $(\mathrm{p}<0,05)$ yang berarti bahwa terdapat jenis hubungan kelamin dengan tingkat kecemasan 11. Berdasarkan penelitian Saragih \& Suparmi (2017) di dapatkan hasil $76,5 \%$ responden perempuan mengalami kecemasan yang tinggi di bandingkan responden laki-laki yang hanya $23,5 \%^{12}$.

3. Pekerjaan

Hasil penelitian dilihat pada table 1 menunjukkan bahwa mayoritas pekerjaan subjek penelitian adalah wiraswasta yang berjumlah 20 orang $(66,7 \%)$.

Kecemasan orang yang bekerja dan tidak bekerja tentu berbeda. Individu yang tidak bekerja cenderung memiliki beban pikiran yang lebih ringan dari pada yang bekerja sehingga beban kerja yang merupakan salah satu faktor kecemasan pada individu tersebut tidak di rasakan, melainkan kecemasan yang dirasakan cenderung diakibatkan oleh faktor lain. Lain halnya dengan orang yang bekerja, kecemasan cenderung diakibatkan oleh beban pekerjaan dan beban urusan rumah tangga. Orang yang bekerja cenderung mengalami stres akibat beban pekerjaan yang dimilikinya.

Pekerjaan adalah sesuatu yang dilakukan individu untuk mencari nafkah atau pencaharian. Pekerjaan yang dilakukan terdapat suatu unsur keharusan untuk dilakukan mengingat untuk memenuhi kebutuhan hidup, sehingga kemungkinan dari suatu pekerjaan yang dilakukan akan menimbulkan kecemasan. Hal tersebut sejalan dengan penelitian yang dilakukan oleh Windatania yang mengatakan bahwa salah satu faktor dari kecemasan adalah pekerjaan. Beban kerja yang dimiliki seseorang seperti merasa dirinya tak kompeten di dunia kerja, atau merasa dirinya tidak mampu memberikan hasil pekerjaan yang maksimal, akan memicu timbulnya kecemasan pada individu tersebut ${ }^{13}$. Proses penerimaan informasi oleh seseorang dimulai pada saat alat indra menangkap stimuli, lalu stimuli tersebut diubah menjadi sinyal yang dapat dimengerti oleh otak untuk kemudian diolah. Disinilah terjadi apa 
yang disebut dengan proses presepsi, yaitu mengerti pesan yang telah diproses oleh system indrawi. Persepsi yang ditimbulkan setiap orang akan berbeda. Dari perbedaan persepsi itu akan menimbulkan stimulus yang berbeda pula ke otak, sehingga bisa mempengaruhi kondisi psikologis si penerima informasi. Jika persepsi yang ditimbulkan adalah positif maka akan memberikan dampak yang positif pula, begtupun sebaliknya ${ }^{14}$

\section{Efektifitas Terapi Relaksasi Autogenik dan Aromaterapi Lavender Terhadap Penurunan Kecemasan Pada Pasien di Ruang ICU}

Hasil analisa uji Paired T test dapat kita lihat dari tabel 2 bahwa terapi relaksasi autogenik dan aromaterapi lavender efektif dalam menurunkan kecemasan pasien di ICU dengan nilai pvalue yang didapat yaitu 0,000 $(\mathrm{P}<0,05)$. Penelitian ini membuktikan bahwa autorelaksasi mampu menurunkan kecemasan. Salah satu penyebab kecemasan adalah penyakit yang dialami individu. Hal lain penyebab kecemasan adalah faktor psikologis diantaranya perasaan bosan, keletihan atau perasaan depresi ${ }^{15}$. Ketika seseorang cemas ia akan merasa tegang, tidak tenang, gelisah dan mudah terkejut. Keluhan lainnya adalah rasa sakit pada otot dan tulang, pendengaran berdenging, berdebar-debar, sesak nafas, gangguan pencernaan, perkemihan, meningkatnya tekanan darah dan nadi, sakit kepala dan lainnya ${ }^{16}$. Relaksasi autogenik membantu tubuh membawa perintah melalui autosugesti untuk rileks sehingga dapat mengendalikan pernafasan, tekanan darah, denyut jantung serta suhu tubuh. Relaksasi autogenik ini juga membantu individu untuk dapat mengendalikan beberapa fungsi tubuh seperti tekanan darah, frekuensi jantung dan aliran darah yang meningkat ketika cemas ${ }^{5}$
Sedangkan pemberian aroma terapi lavender mampu menurunkan tingkat kecemasan hal ini sesuai dengan teori yang diungkapkan oleh Maifrisco (2008), bahwa aromaterapi dapat mempengaruhi bagian otak yang berkaitan dengan mood, emosi, ingatan, dan pembelajaran. Dengan menghirup aromaterapi lavender maka akan meningkatkan gelombang- gelombang alfa di dalam otak dan gelombang inilah yang membantu untuk menciptakan keadaan yang rileks. Terdapat berbagai jenis wewangian aromaterapi yang ada dan setiap wangiwangian tersebut memiliki kelebihan positif yang bermacam-macam. Misalnya, aroma lavender dipercaya dapat mengurangi rasa stres dan mengurangi kesulitan tidur (insomnia). Minyak aromaterapi lavender dikenal sebagai minyak penenang ${ }^{17}$.

\section{KESIMPULAN DAN SARAN}

Terdapat perbedaan skor kecemasan sebelum dan setelah diberikan intervensi Terapi relaksasi autogenic dan aromaterapi lavender pada pasien di Ruang ICU RSUD Poso.

\section{UCAPAN TERIMA KASIH}

Ucapan terima kasih kepada Direktur Poltekkes Kemenkes Palu dan semua pihak yang telah membantu proses penelitian ini.

\section{DAFTAR PUSTAKA}

1. PK RF, Yusuf A, Nihayati HE. No Title. Salemba Medika; 2015.

2. Peni T. Kecemasan Keluarga Pasien Ruang ICU Rumah Sakit Daerah Sidoarjo. Hosp Majapahit. 2014;6(1):86-97.

3. World Health Organization. Mental health ATLAS 2017 state profile.

4. Kementrian Kesehatan Republik Indonesia. Riset Kesehatan Dasar.; 2018.

5. Sudiarto, Suwondo A, Nurrudin A. Pengaruh Relaksasi terhadap Kecemasan dan Kualitas Tidur pada Pasien Intensive Care Unit. J Ris Kesehat. 2015;4(3):847856. 
6. Jannah AR, Jatimi A, Azizah MJ, Munir Z, Rahman HF. Kecemasan Pasien COVID-19: A Systematic Review. J Penelit Kesehat Suara Forikes. 2020;11(2):33-37.

7. Rosida L, Imardiani I, Wahyudi JT. Pengaruh Terapi Relaksasi Autogenik Terhadap Kecemasan Pasien Di Ruang Intensive Care Unit Rumah Sakit Pusri Palembang. Indones $J$ Heal Sci. 2019;3(2):52. doi:10.24269/ijhs.v3i2.1842

8. Umi Istianah U, Sri Hendarsih $H$. Relaksasi Autogenik Untuk Menurunkan Tekanan Darah dan Tingkat Kecemasan Penderita Hipertensi Esensial di Panti Sosial Tresna Wredha Abiyoso Pakem Yogyakarta. $J$ Teknol Kesehat. 2016;12(2):92-100.

9. Stuart G. Principles and Practice of Psychiatric Nursing. 7th ed. Mosby; 2013.

10. Guyton, A. C, Hall JE. Buku Ajar Fisiologi Kedokteran. 12th ed. EGC; 2014.

11. Vellyana D, Lestari A, Rahmawati A. Faktor-Faktor yang Berhubungan dengan Tingkat Kecemasan pada Pasien Preoperative di RS Mitra Husada Pringsewu. J Kesehat. 2017;8(1):108. doi:10.26630/jk.v8i1.403

12. Saragih D, Suparmi Y. Faktor-Faktor Yang Mempengaruhi Tingkat Kecemasan Pasien Yang Dirawat Di Ruang Icu/Iccu Rs Husada Jakarta. Kosala J Ilmu Kesehat. 2017;5(1). doi:10.37831/jik.v5i1.119

13. Windatania M. Menurunkan Tingkat Kecemasan Ibu Hamil Primigravida Menjelang Persalinan Melalui Dukungan Suami dan Status Kesehatan. J Penelit Suara Forikes. 2019;10(April):Lase, D., Ndraha, A., Harefa, G. G. (2020). Pers.

14. Basofi DA, Wilson., Asroruddin M. Hubungan Jenis Kelamin, Pekerjaan dan Status Pernikahan dengan Tingkat Kecemasan Pada Pasien Operasi Katarak di Rumah Sakit Yarsi Pontianak. J Mhs PSPD FK Univ Tanjungpura. 2016;3(1):4-22.

15. Nugroho S. Pengaruh Intervensi Teknik Relaksasi Lima Jari Terhadap Fatigue
Klien Ca Mammae Di Rs Tugurejo Semarang. Published online 2016.

16. Hawari D. Manajemen Stress, Cemas Dan Depresi. 2nd ed. Balai Penerbit Fakultas Kedokteran Indonesia; 2013.

17. Dila RD, Putra F, Fitriani Arifin RS. Pengaruh aromaterapi lavender terhadap penurunan kecemasan ibu pre operasi sectio caesarea di rumah sakit bersalin. Caring Nurs J. 2017;1(2):51-56. 